\title{
The Increase of Ruminant Population Based on Agricultural Waste Potential as Feed in Aceh Tamiang District
}

\author{
Yenni Yusriani $^{1}$, Nora Usrina $^{2}$, and Mustafa Sabri ${ }^{3, *}$ \\ ${ }^{1}$ Aceh Assessment Institute for Agricultural Technology, Indonesia \\ ${ }^{2}$ Indonesian Agricultural Quarantine Development, Indonesia \\ ${ }^{3}$ Faculty of Veterinary Medicine, University of Syiah Kuala, Indonesia
}

\begin{abstract}
Livestock management includes the systems of maintenance, reproduction, and waste utilization. This study aims to examine the potential of feed sources for ruminants (cows and buffaloes) and efforts to maintain continuous feed availability associated with ruminant livestock development strategies. The data used were primary and secondary data of feed sources. Furthermore, the variables observed include cattle and buffalo population, agricultural waste production, digested dry matter (DDM), and carrying capacity. The results showed that Seruway sub-district had the highest population of cattle with 8,378 cows $(4,933$ ST) or $20.35 \%$ while Karang Baru sub-district had the highest population of 70 buffalo (34 ST) or $40.23 \%$. Meanwhile, Manyak Payed sub-district produced the highest agricultural waste with 5,029.32 DDM tons/year while the low district was Kuala Simpang city. Moreover, the commodity that produces the highest agricultural waste is rice which is scattered in all districts with a total of 19,370.65 DDM tons/year. Although the cassava plant was not in all districts, it has the potential of producing 48,154.5 tons/year DDM. Furthermore, the sub-district with a great opportunity was Karang Baru which produces an unutilized potential of 2,718.23 tons/year and a carrying capacity of 2,384.41 (ST/year). This showed that Kejuruan Muda subdistrict has insufficient agricultural waste for cattle and buffalo, therefore, breeders in this sub-district get feed from the plantation and other wastes. Based on the results, Aceh Tamiang district has the potential to increase the ruminants population by utilizing forage feed from agricultural waste.

Keywords: population increase, ruminants, feed
\end{abstract}

\section{Introduction}

One of the steps to reduce feed limitations is the utilization of waste as a source of feed for ruminants which minimizes costs and increases livestock populations. Meanwhile, the existing nutritional value that supports the growth and development of livestock includes rice straw containing $4.55 \%$ crude protein [1] and fermented rice straw containing crude protein $6.23-6.56 \%$ [2]. Currently, the varieties of beans dominating the market are soybeans, most

\footnotetext{
*Corresponding author: mustafa_sabriyosa@yahoo.com
} 
of which are imported. Therefore, an effort is required to use local nuts as a source of cheap vegetable protein for humans [3] while the waste is used as ruminants feed.

Cattle and buffalo livestock are renewable natural resources that have the potential to be developed. The development effort is concerned about the availability of natural resources that increase economic growth to support people's welfare. Furthermore, it also preserves natural resources and social disparities to improve the quality of life which is, currently known as sustainable development. Meanwhile, the development of cattle and buffalo businesses is expected to increase the population which leads to an increase in the supply of domestic beef and buffalo. These efforts also ultimately increase the income and welfare of farmers [4]. Moreover, animal husbandry technology innovation plays an important role in supporting the development of an integrated agricultural model. The application of technology in the integrated system is more emphasized to meet the needs of animal feed through processing plant waste [5] so that farmers overcome the feed availability problem by utilizing agricultural waste in the integrated system [6]. This integrated system is very profitable because livestock is used as feed. Furthermore, livestock produces manure as organic fertilizer to increase soil fertility and compost income. Moreover, the agricultural waste given to livestock is to be a mixture of different agricultural wastes [7].

This study aims to examine the potential sources of feed for ruminants (cows and buffaloes) and efforts to maintain continuous feed availability associated with ruminant livestock development strategies. Therefore, the ruminant livestock business is more efficient and beneficial for breeders, especially in Aceh Tamiang District. The results are expected to provide important information to related agencies, the communities, and breeders in terms of ruminants' development by utilizing agricultural waste.

\section{Material and Method}

\subsection{Place and Time of Research}

The study was conducted from January 2017 to December 2018 in Aceh Tamiang District, Aceh Province.

\subsection{Types and Data Collection}

This study is exploratory through primary and secondary data analysis. The secondary data are in form of livestock population and food crop production. The data was from the Central Statistics Agency of Aceh Tamiang District in 2018 [8]. Based on secondary data, the calculation of the number of livestock units, agricultural waste production, and livestock capacity was calculated. Furthermore, other supporting data relating to this study were from previous studies and various literature sources.

\subsection{Observed Variables}

The observed variables are as follows:

(1). The population data for large ruminants is calculated [9] based on the population structure of the production level (weaning, off weaning, young, adult, and imported cattle) and buffalo (off weaning, young, and adult). Age is (a) weaners with age $<1$ year have a composition of $19.30 \%$ of the population, (b) off weaning $>1$ year old has a composition of $25.85 \%$ of the population, (c) Young people aged 2 to 4 years have a composition of $18.15 \%$, (d) Adults $>4$ years old have a composition of $26.89 \%$, and (5) Imported cattle have a 
composition of $9.81 \%$. For buffalo livestock with a buffalo population structure based on age are (a) Lepas Sapih with a composition of $16.32 \%$ of the population, (b) Young with a composition of $20.67 \%$ of the population, (c) Adults (2 to 4 years) with a composition of $20.74 \%$, and (d) Adults ( $>4$ years) with a composition of $42.27 \%$. Furthermore, the population according to age is converted into Livestock Unit (ST), which is equalized to one adult ruminant livestock. The unit value of beef cattle stated by [10] is $0.25 \mathrm{ST}$ for children (weaning and weaning), 0.6 ST (young), and 1.00 (adult and imported). The unit value of buffalo is calculated according to [11] which is $0.8 \mathrm{ST}$.

(2). The minimum forage needed for large ruminants using the calculation of [12] is 1.14 tons DDM /year

(3). The estimates of agricultural waste production per hectare per year are calculated based on estimates of food crop production with data sources from the Food Crops and Horticulture Office of Aceh Tamiang District according to [12].

\section{Result and Discussion}

\subsection{Geographical Condition of Aceh Tamiang District}

Aceh Tamiang District is one of the administrative areas of Aceh Province, located at a geographical position of $04^{\circ} 32^{\prime} 56.76^{\prime \prime}$ North Latitude and $98^{\circ} 14^{\prime} 45.41^{\prime \prime}$ East Longitude. This district has an area of $1957.02 \mathrm{~km} 2$ with its capital Karang Baru covering 12 sub-districts and 213 villages. Furthermore, the district is adjacent to the capital city of North Sumatra province making it the main gateway and has the opportunity to grow. This makes it easy to interact with other districts, mobilizes goods and services such as high agricultural and livestock production. Therefore, the agricultural and livestock sectors influence the economy of Aceh Tamiang District.

\subsection{Large Ruminant Population}

Livestock management includes systems of maintenance, livestock health, reproduction, and utilization of agricultural waste. Meanwhile, the program organized by the government through the livestock office to carry out the SIWAB program includes data collection for Artificial Insemination (IB) for pregnancy, birth, and other related data. Moreover, the Aceh Tamiang district is one of the areas used for ruminant livestock development. This condition makes the area a target and destination in various things such as the development of cattle business. The population of cattle in Aceh Province in 2018 was 603,415 cows while Aceh Tamiang District was one of the largest populations with 77,955 cows.

Based on Table 1, the area with the highest population of cattle was the Seruway subdistrict with 8,378 cows $(4,933 \mathrm{ST})$ or $20.35 \%$ followed by Kejuruan Muda sub-district with 6,108 cows $(3,596 \mathrm{ST}) 14.83 \%$ and Tenggulun sub-district with a total of 5,134 cows $(3,023$ ST) $12.47 \%$ while the lowest sub-district was Kuala Simpang city with 27 cows (16 ST) $0.07 \%$.

Furthermore, Table 2 shows the area with the highest population of buffalo, namely the Karang Baru sub-district with a total of 70 cows (34 ST) or $40.23 \%$ followed by the Kejuruan Muda sub-district with a total of 29 cows (14 ST) or $16.67 \%$, Bandar Pusaka as well as Bendahara sub-districts with 24 (12 ST) or $13.79 \%$, and the lowest sub-district is Sekerak sub-district with 11 cows (5 ST) or $6.32 \%$ 
Table 1. Beef cattle population by age and conversion to livestock units (ST)

\begin{tabular}{|c|c|c|c|c|c|c|c|c|}
\hline $\begin{array}{l}\text { Sub } \\
\text { district }\end{array}$ & $\begin{array}{l}\begin{array}{l}\text { Beef } \\
\text { cattle } \\
\text { Population } \\
(\text { head })^{1}\end{array} \\
\end{array}$ & $\begin{array}{l}\text { Populati } \\
\text { on of } \\
\text { weaner } \\
\text { cattle } \\
(\text { head })^{2}\end{array}$ & $\begin{array}{l}\text { Population } \\
\text { of growing } \\
\text { beef cattle } \\
\text { (head) })^{2}\end{array}$ & $\begin{array}{l}\text { Populatio } \\
\text { n of } \\
\text { mature } \\
\text { beef } \\
\text { cattle } \\
(\text { head })^{2}\end{array}$ & $\begin{array}{l}\begin{array}{l}\text { Adult } \\
\text { (head) }\end{array} \\
\text { (he }\end{array}$ & $\begin{array}{l}\text { Importe } \\
\text { d beef } \\
\text { cattle } \\
\text { Population } \\
\text { (head) }^{2}\end{array}$ & $\begin{array}{l}\text { Total beef } \\
\text { cattle } \\
\text { population } \\
(\mathrm{ST})^{3}\end{array}$ & $(\%)$ \\
\hline $\begin{array}{l}\text { Tamiang } \\
\text { Hulu }\end{array}$ & 2.289 & 441.78 & 591.71 & 415.45 & 615.51 & 224.55 & 1348 & 5.56 \\
\hline $\begin{array}{l}\text { Bandar } \\
\text { Pusaka }\end{array}$ & 971 & 187.40 & 251.00 & 176.24 & 261.10 & 95.26 & 572 & 2.36 \\
\hline $\begin{array}{l}\text { Kejuruan } \\
\text { Muda }\end{array}$ & 6.108 & $1,178.8$ & $1,578.92$ & $1,108.6$ & $1,642.4$ & 599.19 & 3596 & 14.83 \\
\hline Tenggulun & 5.134 & 990.86 & $1,327.14$ & 931.82 & $1,380.5$ & 503.65 & 3023 & 12.47 \\
\hline Rantau & 3.999 & 771.81 & $1,033.74$ & 725.82 & $1,075.3$ & 392.30 & 2355 & 9.71 \\
\hline $\begin{array}{l}\text { Kota } \\
\text { Kuala } \\
\text { Simpang }\end{array}$ & 27 & 5.21 & 6.98 & 4.90 & 7.26 & 2.65 & 16 & 0.07 \\
\hline Seruway & 8.378 & $1,616.9$ & $2,165.71$ & $1,520.6$ & $2,252.8$ & 821.88 & 4933 & 20.35 \\
\hline Bendahara & 2.956 & 570.51 & 764.13 & 536.51 & 794.87 & 289.98 & 1740 & 7.18 \\
\hline $\begin{array}{l}\text { Banda } \\
\text { Mulia }\end{array}$ & 2.585 & 498.91 & 668.22 & 469.18 & 695.11 & 253.59 & 1522 & 6.28 \\
\hline $\begin{array}{l}\text { Karang } \\
\text { Baru }\end{array}$ & 5.033 & 971.37 & $1,301.03$ & 913.49 & $1,353.3$ & 493.74 & 2963 & 12.22 \\
\hline Sekerak & 411 & 79.32 & 106.24 & 74.60 & 110.52 & 40.32 & 242 & 1.00 \\
\hline $\begin{array}{l}\text { Minyak } \\
\text { Payed }\end{array}$ & 3. 288 & 634.58 & 849.95 & 596.77 & 884.14 & 322.55 & 1936 & 7.98 \\
\hline Total & 41179.00 & 7947.5 & 10644.77 & 7473.9 & 11073.03 & 4039.66 & 24245.17 & 100.00 \\
\hline
\end{tabular}

Remark: ${ }^{1)}[8] ;{ }^{2)}[9] ;{ }^{3)}[11]$

Table 2. The population of buffalo based on age and conversion to livestock units (ST)

\begin{tabular}{|c|c|c|c|c|c|c|c|}
\hline Sub district & \begin{tabular}{|l|}
$\begin{array}{l}\text { Buffalo } \\
\text { Population } \\
\text { (head) }^{1}\end{array}$ \\
\end{tabular} & $\begin{array}{l}\text { Population } \\
\text { of weaner } \\
\text { buffalo } \\
\text { (head) })^{2}\end{array}$ & $\begin{array}{l}\text { Populatio } \\
\text { n growing } \\
\text { buffalo } \\
\text { (head) }^{2}\end{array}$ & $\begin{array}{l}\text { Population } \\
\text { mature }(2-4 \\
\text { yr) }(\text { head })^{2}\end{array}$ & $\begin{array}{l}\text { Population } \\
\text { mature }(>4 \\
\text { yr) }(\text { head })^{2}\end{array}$ & $\begin{array}{l}\text { Total } \\
\text { Buffalo } \\
\text { populati } \\
\text { on }(\mathrm{ST})^{3}\end{array}$ & $\begin{array}{c}\text { Percentage } \\
(\%)\end{array}$ \\
\hline $\begin{array}{l}\text { Tamiang } \\
\text { Hulu }\end{array}$ & 0 & 0 & 0 & 0 & 0 & 0 & 0.00 \\
\hline $\begin{array}{l}\text { Bandar } \\
\text { Pusaka }\end{array}$ & 24 & 5 & 6 & 4 & 6 & 12 & 13.79 \\
\hline $\begin{array}{l}\text { Kejuruan } \\
\text { Muda }\end{array}$ & 29 & 6 & 7 & 5 & 8 & 14 & 16.67 \\
\hline Tenggulun & 0 & 0 & 0 & 0 & 0 & 0 & 0.00 \\
\hline Rantau & 0 & 0 & 0 & 0 & 0 & 0 & 0.00 \\
\hline $\begin{array}{l}\text { Kota Kuala } \\
\text { Simpang }\end{array}$ & 0 & 0 & 0 & 0 & 0 & 0 & 0.00 \\
\hline Seruway & 16 & 3 & 4 & 3 & 4 & 8 & 9.20 \\
\hline Bendahara & 24 & 5 & 6 & 4 & 6 & 12 & 13.79 \\
\hline Banda Mulia & 0 & 0 & 0 & 0 & 0 & 0 & 0.00 \\
\hline Karang Baru & 70 & 14 & 18 & 13 & 19 & 34 & 40.23 \\
\hline Sekerak & 11 & 2 & 3 & 2 & 3 & 5 & 6.32 \\
\hline $\begin{array}{l}\text { Minyak } \\
\text { Payed }\end{array}$ & 0 & 0 & 0 & 0 & 0 & 0 & 0.00 \\
\hline Total & 174.00 & 33.58 & 444.98 & 31.58 & 46.79 & 85 & 100.00 \\
\hline
\end{tabular}

Remark: ${ }^{1)}[8] ;{ }^{2)}[9] ;{ }^{3)}[1]$ 
The system of selling cattle and buffalo is carried out at the animal market which is one of the driving forces for livestock development. Meanwhile, the animal market is easily accessible to breeders which makes it easier to sell livestock without going through agents or traders. Therefore, it is more profitable for farmers because the marketing margin is conducted directly.

\subsection{The Potential of Feed to Increase Animal Population}

The results of a previous study conducted in Aceh Tamiang District, namely the use of palm oil waste in local cattle and Brahman cattle showed that provision of frond silage + concentrate was able to increase daily live weight gain of $0.34 \mathrm{~kg} / \mathrm{cattle} / \mathrm{day}$ [13] and 0.99 $\mathrm{kg} / \mathrm{cattle} /$ day of Brahman cattle [14]. This showed that the provision of agricultural waste increases the livestock population. Meanwhile, the majority of the societies in this district work as experienced farmers/breeders in producing agricultural and plantation commodities. The residents with such a livelihood pattern develop different types of livestock to meet both family needs and for sale.

Plant waste such as leaves is processed into animal feed in form of fresh or fermented feed $[15 ; 16 ; 17]$. Furthermore [18] stated that agricultural land has considerable potential as a source of feed. Therefore, the forage evaluation which is shown to predict the potential of livestock in the study area is needed to support the increase of capacity for ruminants population concerning regional development planning and potential. One of the factors determining the success of livestock development is the availability of sufficient feed-in quantity, quality, and the sustainable way [19;20;21], therefore, waste utilization is important as an alternative to cheap animal feed that is easily obtained.

Based on Table 3, the high total production of agricultural waste is in the Manyak payed sub-district with 5,029.32 DDM tons/year, followed by the Bendahara sub-district with 3,473.06 DDM tons/year, and Karang Baru sub-district with 3,098.78 DDM tons/year. Furthermore, Kuala Simpang City was a subdistrict with low production because it is the capital of Aceh Tamiang District. Meanwhile, the agricultural commodities producing the most and scattered agricultural waste in all districts were rice with 19,370.65 tons/year of DDM and corn with 1,094.95 tons/year. Although cassava also has the potential of 48,154.5 tons/DDM year, it is unavailable in all sub-districts.

The results of the study by [22] showed that providing fresh forage alone as animal feed is inefficient without additional feed. Although a large volume of forage is given, the amount of nutrients obtained is not sufficient when given solely. Therefore, the daily weight growth target is difficult to achieve which makes the livestock business uneconomical. This makes it necessary to use other feed ingredients as supplements to enhance productivity. Meanwhile, the potential local feed ingredients from agricultural agro-industries consist of rice bran, corn, tofu dregs, and fiber feed while ingredients from agricultural waste include rice straw, corn stalks, bean straw, and cassava forage.

Moreover, animal reproduction performance is closely related to reproductive and feed management. This reproductive management is one of the main aspects of the survival of the livestock business [23]. Furthermore, the availability of sufficient quantity and quality of forage is one of the factors that determine the success of a business in livestock development [24]. Meanwhile, [25] stated that feed is a very important means of livestock production because it functions as a material to stimulate livestock growth. 
Table 3.Feed Potential and Total Agricultural Waste Production (DDM ton/year) in Aceh Tamiang District, 2018

\begin{tabular}{|l|r|r|r|r|r|r|r|}
\hline Sub district & \multicolumn{1}{|c|}{ Rice } & \multicolumn{1}{c|}{ Corn } & \multicolumn{1}{c|}{ Soy } & \multicolumn{1}{c|}{$\begin{array}{l}\text { Green } \\
\text { beans }\end{array}$} & Peanuts & Cassava & $\begin{array}{l}\text { Total } \\
\text { Waste } \\
\text { Production } \\
\text { (DDM ton / } \\
\text { yr) }\end{array}$ \\
\hline Tamiang Hulu & 453.21 & 46.5 & 0 & 0 & 0 & 0 & 499.71 \\
\hline Bandar Pusaka & 643.51 & 516.75 & 28.71 & 3.2058 & 0.9864 & 29.889 & 1.223 .05 \\
\hline $\begin{array}{l}\text { Kejuruan } \\
\text { Muda }\end{array}$ & 441.66 & 98.55 & 0 & 0 & 0 & 0 & 540.21 \\
\hline Tenggulun & 149.35 & 14.85 & 0 & 0.6576 & 0.6576 & 0.972 & 166.49 \\
\hline Rantau & 999.91 & 0.6354 & 18.744 & 0 & 0 & 3.24 & 1.022 .53 \\
\hline $\begin{array}{l}\text { Kota Kuala } \\
\text { Simpang }\end{array}$ & 0 & 64.8 & 0 & 0 & 0 & 0 & 64.80 \\
\hline Seruway & 2.837 .80 & 0.9 & 1.65 & 0 & 0.3836 & 0 & 2.840 .73 \\
\hline Bendahara & 3.430 .98 & 0 & 0 & 0.6576 & 0 & 5.427 & 3.437 .06 \\
\hline Banda Mulia & 2.332 .18 & 163.62 & 2.904 & 0.7672 & 0.822 & 0 & 2.500 .29 \\
\hline Karang Baru & 3.075 .42 & 1.41 & 15.873 & 0 & 0 & 6.075 & 3.098 .78 \\
\hline Sekerak & 92.06 & 85.68 & 0 & 0 & 0 & 0 & 177.74 \\
\hline Minyak Payed & 4.914 .57 & 101.25 & 10.56 & 0.3836 & 0 & 2.5515 & 5.029 .32 \\
\hline Total & $\mathbf{1 9 . 3 7 0 . 6 5}$ & $\mathbf{1 . 0 9 4 . 9 5}$ & $\mathbf{7 8 . 4 4 1}$ & $\mathbf{5 . 6 7 1 . 8}$ & $\mathbf{2 . 8 4 9 . 6}$ & $\mathbf{4 8 . 1 5 4 . 5}$ & $\mathbf{2 0 . 6 0 0 . 7 1}$ \\
\hline
\end{tabular}

Also, [26] stated that approximately $90 \%$ of national beef production comes from smallholder farms while the remaining $10 \%$ is from companies. The development of livestock agribusiness is closely related to feeding, especially forage for cattle, approximately $70 \%$ is determined by the environment, most importantly feed and $30 \%$ is genetic [27]. Increasing the number of livestock is followed by the efforts to meet feed needs, especially potential forage plants with high nutritional value and well adapted to various environments [28].

\subsection{Regional Carrying Capacity Based on The Potential Feed}

The carrying capacity of agricultural waste is the ability of an area to produce animal feed in form of agricultural waste that meets the needs of ruminant livestock in fresh or dry form without special processing. Moreover, the remainder of the food crops are usually used as animal feed and the production depends on the harvesting area. This carrying capacity is one of the important factors to support the increase of livestock productivity and achieve optimal results [29]. Furthermore, the level of forage availability in an area is one of the most important factors in increasing the population which leads to the successful development of ruminants [30].

Generally, sub-districts in Aceh Tamiang have the potential for livestock development. Based on Table 4, the sub-districts that have the greatest opportunity were Karang Baru and Bendahara by producing unutilized potential of 2,718.23 tons/year and 3, 014.97 tons/year with a capacity of 2,384.41 (ST/year) and 2,644.71 (ST/year) respectively. Meanwhile, the sub-district without potential was the Kejuruan Muda because it has insufficient agricultural waste products for cattle and buffalo. Therefore, breeders in this district get feed from the plantation and other wastes that are used as animal feed. The Karang Baru sub-district remains a very big chance of increasing ruminant livestock, especially buffalo as the Indonesian germplasm that contributed to the meat self-sufficiency program was recognized in 2010 [31]. 
The potential amount of agricultural waste is the current feed availability. Moreover, the high carrying capacity value is by the production of agricultural waste. When agricultural waste production is high, it affects the carrying capacity of an area. This shows that the production of agricultural waste helps in the provision of feed for ruminants. The low carrying capacity showed that the production of agricultural waste in the district is low. This low production is caused by the geographical conditions of the district which makes it impossible to meet ruminants' needs with a high population.

Technically, several attempts have been made to develop livestock businesses without political and socio-cultural (cultural) support and the results were less than optimal [32]. Human resources are important factors in livestock development that determine the success or failure of a region's development. Meanwhile, human resources that are closely related to a livestock business are breeders. Generally, Aceh Tamiang District has a population of 291,112 people with $58.89 \%$ working in the agriculture and forestry sector including 11 doctors and 5 veterinarians [8]. A study conducted by [33] stated that agricultural waste contributes to large and small ruminant livestock businesses, therefore, it is important to manage the natural resources that are used as ruminant animal feed. The existence of agricultural land is a huge benefit for the development of ruminants economically, socially, and environmentally. This determines the economic growth, especially for the progress of society [34] in the Aceh Tamiang district.

Table 4.Beef cattle and buffalo population on livestock unit, feed requirement, and carrying capacity

\begin{tabular}{|l|r|r|r|r|r|r|r|r|}
\hline Subdistrict & $\begin{array}{l}\text { Beef } \\
\text { Cattle } \\
\text { Population } \\
\text { (ST) }\end{array}$ & $\begin{array}{l}\text { DMD } \\
\text { Requir- } \\
\text { ement of } \\
\text { beef cattle } \\
\text { (ton/year) }\end{array}$ & $\begin{array}{l}\text { Buffalo } \\
\text { populati } \\
\text { on (ST) }\end{array}$ & $\begin{array}{l}\text { DMD } \\
\text { Require- } \\
\text { ment of } \\
\text { buffalo } \\
\text { (ton/year) }\end{array}$ & $\begin{array}{l}\text { Total } \\
\text { require- } \\
\text { ment of } \\
\text { DMD } \\
\text { (ton/year) }\end{array}$ & $\begin{array}{l}\text { DMD } \\
\text { production } \\
\text { ton/year) }\end{array}$ & $\begin{array}{l}\text { The } \\
\text { potential } \\
\text { of DMD } \\
\text { has not } \\
\text { been } \\
\text { utilized } \\
\text { (ton/year) }\end{array}$ & $\begin{array}{l}\text { Carrying } \\
\text { capacity } \\
\text { (LU/year) }\end{array}$ \\
\hline $\begin{array}{l}\text { Tamiang } \\
\text { Hulu }\end{array}$ & 1348 & 1536 & 0 & 0 & 1.536 .38 & 499.71 & -1036.68 & -909.37 \\
\hline $\begin{array}{l}\text { Bandar } \\
\text { Pusaka }\end{array}$ & 572 & 652 & 12 & 13 & 665.16 & 1.223 .05 & 557.89 & 489.38 \\
\hline $\begin{array}{l}\text { Kejuruan } \\
\text { Muda }\end{array}$ & 3596 & 4100 & 14 & 16 & 4.115 .93 & 540.21 & -3575.72 & -3136.60 \\
\hline Tenggulun & 3023 & 3446 & 0 & 0 & 3.445 .96 & 166.49 & 146.04 & 128.11 \\
\hline Rantau & 2355 & 2684 & 0 & 0 & 2.684 .14 & 1.022 .53 & 896.95 & 786.80 \\
\hline $\begin{array}{l}\text { Kota Kuala } \\
\text { Simpang }\end{array}$ & 16 & 18 & 0 & 0 & 18.12 & 64.80 & 56.84 & 49.86 \\
\hline Seruway & 4933 & 5623 & 8 & 9 & 5.632 .29 & 2.840 .73 & 2491.87 & 2185.85 \\
\hline Bendahara & 1740 & 1984 & 12 & 13 & 1.997 .50 & 3.437 .06 & 3014.97 & 2644.71 \\
\hline $\begin{array}{l}\text { Banda } \\
\text { Mulia }\end{array}$ & 1522 & 1735 & 0 & 0 & 1.735 .06 & 2.500 .29 & 2193.24 & 1923.89 \\
\hline $\begin{array}{l}\text { Karang } \\
\text { Baru }\end{array}$ & 2963 & 3378 & 34 & 39 & 3.417 .32 & 3.098 .78 & 2718.23 & 2384.41 \\
\hline Sekerak & 242 & 276 & 5 & 6 & 282.02 & 177.74 & 155.92 & 136.77 \\
\hline $\begin{array}{l}\text { Minyak } \\
\text { Payed }\end{array}$ & 1936 & 2207 & 0 & 0 & 2.206 .92 & 5.029 .32 & 4411.68 & 3869.90 \\
\hline Total & $\mathbf{2 4 2 4 5 .}$ & $\mathbf{2 7 . 6 3 9 . 4}$ & $\mathbf{8 5}$ & $\mathbf{9 7 . 3 3}$ & $\mathbf{2 7 . 7 3 6 . 8}$ & $\mathbf{2 0 . 6 0 0 . 7 1}$ & $\mathbf{1 . 2 0 3 1 . 2 3}$ & $\mathbf{1 0 . 5 5 3 . 7 1}$ \\
\hline
\end{tabular}

\section{Conclusion}

Based on the results, the sub-district with great opportunity for livestock development is the Karang Baru sub-district by producing an unutilized potential of 2.718.23 tons/year and a carrying capacity of 2.384.41 (ST/year). This is followed by the Bendahara sub-district with 
3. 014.97 tons /year of unutilized potential and a carrying capacity of 2.644.71 (ST/year). Meanwhile, the sub-district without potential is the Kejuruan Muda because of insufficient agricultural waste products for cattle and buffalo. Therefore, breeders in this sub-district get feed from the plantation and other wastes. Forage availability is one of the determining factors for the success of breeders' businesses. Hence, the provision of quality forage generates optimal benefits for breeders.

\section{References}

1. Sirait. J and Simanihuruk K., Wartazoa, 20 (2): 75-84 (2010).

2. Sudarwati H and Susilawati T., Journal of Tropical Livestock, 14 (2): 23-30 (2013).

3. Ekafitria R, Isworo R., Food Journal, 23 (2): 134-145 (2014).

4. Yusriani Y., Beef Cattle Reproduction Performance Through Mineral Block and Indigofera Innovation and Technology in Bener Meriah and Central Aceh Districts, Acceleration of Increased Productivity of Beef and Buffalo Cows through Innovative Technology Supporting Special Efforts to SIWAB. C2020 IAARD PRESS. Anggota IKAPI No: 445/DKI/2018. ISBN 978-602-344-298-0. Pp 377-402 (2020).

5. Yusriani Y., Utilization of Local Resources and Bio-industrial Agricultural Policy, ISBN: 978-623-93937-8-6. Anggota IKAPI, No. 323/JBA/2018. Pp 19-34 (2020).

6. Yusriani Y, Elviwirda, Sabri M.,Journal of Indonesian Animal Husbandry. ISSN 19071760, 17 (2): 163-169 (2015)

7. Suryana., Journal of Agricultural Research, 28 (1): 25-34 (2009).

8. Aceh Tamiang Central Statistics Agency. Aceh Tamiang District in Figures. Publisher BPS Bireun Regency (2019).

9. Directorate General of Animal Husbandry RI., General Guidelines for the Development of Cattle Integration in 2012, Directorate General of Animal Husbandry, Ministry of Agriculture, Republic of Indonesia. Jakarta (2011)

10. Nell AJ, Rollington DHL., The Requirement and Availability of Livestock Feed in Indonesia., Jakarta, Indonesia: Working Paper (1974).

11. Ashari, F., E. Juarini, Sumanto, B. Wibowo dan Suratman., Guidelines for analysis of potential areas for distribution and development of livestock, Center for Animal Research and Directorate of Livestock Spread and Development Development, Jakarta (1995)

12. Sumanto and E. Juarini., Guidelines for Regional Potential Identification, Ciawi-Bogor Animal Research Institute, Bogor (2006)

13. Yusriani Y, Sabri M, Rahayu NI, Rahayu ET, Elviwirda, Adriani R. Access Livest. Anim. Res., July 2020, 18(2): 180-190. p-ISSN 2721-5326 e-ISSN 2721-7086 https://doi.org/ 10.20961/lar.v18i2.42997 (2020).

14. Rahma FF, Sabri M and Yusriani Y., Implementation of Palm, Corn and Indigofera on Brahman Cattle Rations in Aceh Tamiang District. Proceedings of the 2020 National Webinar on Perception of "Contribution of Local Livestock Business Before and After the Pandemic in Fulfilling Animal Protein in Indonesia", Andalas University. ISBN: 978-623-7763-28-4. Pp 186-197 (2020).

15. Rawung, J.B.M. and B. Bakrie., International Journal of Environment, Agriculture and Biotechnology, 3(4):1331-1339 (2018). 
16. Afrizon, U.P. Astuti, and S. Yuliasari., Development of bio-industrial agriculture based on coffee and cattle in Bengkulu Province in the Book of Biodiversity Farming, Future Agricultural Solutions. IAARD Press. Pp 179-192 (2018).

17. Yusriani Y, Chairunnas, Asmairecen S., Utilization of Local Resources of SoybeanGoats in Bioindustrial Agriculture in Bireun Regency in the Book of Biotechnology Agriculture, Agricultural Solutions for the Future. IAARD Press. Pp 277-288 (2018).

18. Pangajouw A, Wantasen E, Lenzun GD, Lumenta IDR., Journal Zootek 36 (2):322-332 (2016).

19. Elly FH, Manese MAV and Polakit D., Jounal of Tropica Forage science (Pastura). ISSN 2088-818x. 2 (2): 61-65 (2012).

20. Hastuti D, Shofia Nur A and Baginda Iskandar M., Journal Agricultural Science 7 (1): 55-65 (2011).

21. Gustiani E and K. Permadi K., Jurnal Peternakan Indonesia, ISSN 1907-1760. 17 (1):1218 (2015).

22. Burhaman B., Wartazoa. 21 (3): 133-144 (2011).

23. Suharyati S and M. Hartono. The Influence of Farmer Management on Bali Cattle Reproduction Effeciency in Pringsewu Regency, Lampung Province. 16 (1): 61-67 (2016).

24. Diwyanto. K., S. Rusdiana and B. Wibowo., Wartazoa. 20 (1): 21-42 (2010).

25. Mathius, I W., Wartazoa. 1(2): 206-224 (2008).

26. Atmakusuma J. Harmini and Ratna W., Journal of Treatise on Agricultural and Environmental Policy. 1(2): 105-109 (2011).

27. Bamualim. A., Development of Beef Cattle Feed Technology in SemiArid Nusa Tenggara. Oration Inauguration of Research Professor in the Field of Ruminant Breeding (Animal Feed and Nutrition). Ministry of Agriculture (2010).

28. Rasali, H. Matondang and S. Rusdiana., Journal of Agricultural Research and Development 32 (3): 132-138 (2013).

29. Sengkey NM, Salendu AHS, Wantasen E, Waleleng POV., Zootek Journal. ISSN 08522626. 37 (2): 350-359 (2017).

30. Rusdiana S and Adawiyah CR., SEPA Journal 10 (2): 21-25 (2013).

31. Utami LS, S. Baba, S. Nurani and Sirajuddin SN., JITP, 4(3): 146-150 (2016).

32. Mayulu H, Sunarso, Sutrisno CI and Sumarsono., Journal Agricultural Research and Development, 29(1): 34-41 (2010).

33. Saptana, Journal FAE 30(2):109-128 (2012).

34. Sunartomo, A., Agriekonomika 4(1): 22-36 (2015) 